\title{
Risk assessment of heavy metal soil pollution through principal components analysis and false color composition in Hamadan Province, Iran
}

\author{
Alireza Soffianian ${ }^{1 *}$, Elham Sadat Madani ${ }^{2}$ and Mahnaz Arabi ${ }^{2,3}$
}

\begin{abstract}
Background: In the process of decision making to combat heavy metals pollution, it is essential to have accurate quantitative information about heavy metals and their pollution hot-spots. The main purpose of this study was to determine spatial distribution of several elements ( $\mathrm{As}, \mathrm{Sb}, \mathrm{Cr}, \mathrm{Cd}, \mathrm{Ni}, \mathrm{Co}, \mathrm{Cu}, \mathrm{Zn}, \mathrm{Pb}$, Fe and $\mathrm{V}$ ) on surface soils of Hamadan Province (Iran). It also sought to create a holistic view to determine the position, level, and anomaly of classified elements through principal components analysis (PCA), false color composition (FCC), inverse overlay method, and weighted linear combination. Finally, it tried to identify possible sources of pollution in the hotspots. Interpolation of heavy metal concentrations was performed using geostatistical methods and correlation analysis for locations. The most appropriate interpolation method was selected based on mean absolute error (MAE) and mean bias error (MBE) indices.

Results: According to Pearson's correlation analysis, the elements were categorized in four groups ( $\mathrm{Fe}, \mathrm{V}$, and $\mathrm{Co}$; $\mathrm{Cu}, \mathrm{Ni}$, and $\mathrm{Cr} ; \mathrm{Pb}, \mathrm{Zn}$, and $\mathrm{As} ; \mathrm{Sb}$ and $\mathrm{Cd}$ ). For $\mathrm{Fe}, \mathrm{Zn}, \mathrm{As}$, and $\mathrm{Pb}$, the best method was disjunctive kriging. For $\mathrm{Co}$, $\mathrm{Sb}, \mathrm{Ni}$, and $\mathrm{Cr}$, ordinary kriging was the most appropriate. Radial basic functions was also the best method for $\mathrm{Cd}$ and $\mathrm{Cu}$.

Conclusions: Overlaying of zoning maps of the elements and land use and geological layer maps showed that the distribution pattern of the studied elements did not fully conform to the existing land use pattern. Although the most influential factor on the concentration of elements in the studied soils was bedrocks, extensive use of chemical fertilizers should not be ignored. Moreover, urban pollution can also contribute to Pb contamination of soil.
\end{abstract}

Keywords: Kriging; Correlation analysis; Principal components analysis; False color composition; Inverse overlay method; Weighted linear combination

\section{Background}

Soil is a major natural resource whose properties and quality can be adversely affected by the over-concentration of agricultural and industrial activities. On the other hand, preserving soil quality and preventing its deterioration are fundamental to sustainable development. In recent decades, problems associated with increasing levels of heavy metals and their persistence in the environment have attracted the attention of researchers (Bowen 1979; Lindsay 1979; Lame and Leenaers 1997). Although low concentrations of these metals are naturally found in soils and

\footnotetext{
* Correspondence: soffianian@cc.iut.ac

'Department of Natural Resources, Isfahan University of Technology, Isfahan 84156-93111, Iran

Full list of author information is available at the end of the article
}

stones, human activities have elevated their release and propagation in the environment.

Determining the areas that are polluted either naturally or as a result of human activities is a means of evaluating the health of an ecosystem (Romic et al. 2007). Mining, industries, road transfer, waste burning, and agricultural use of fertilizers and chemicals are human activities that can lead to heavy metal contamination of the soil. On the other hand, natural factors contributing to heavy metal contamination of the soil include volcanoes, degassing of the Earth's crust, fires in forests, and chemical composition of parent materials (Lado et al. 2008).

A variety of sciences such as classical statistics, geostatistics, remote sensing, geographical information systems (GIS), soil science, and hydrology are employed to precisely 
assess the heavy metal content of soils. In fact, soil pollution can currently be well determined using GIS and geostatistical methods. While classical statistical methods have been widely applied in previous studies on soil contamination, such methods are expensive and time-consuming and do not calculate estimation errors. Besides, preparing sufficient samples from the areas under-study is impossible. Hence, geostatistical methods have replaced classical statistics as they can accurately identify time and spatial changes of pollutants and calculate estimation error (Blom 1985; Bonham-carter et al. 1987).

The present research aimed to determine areas with heavy metal $(\mathrm{Cu}, \mathrm{Co}, \mathrm{Ni}, \mathrm{Cd}, \mathrm{Cr}, \mathrm{Sb}, \mathrm{V}, \mathrm{Fe}, \mathrm{Pb}, \mathrm{As}$, and $\mathrm{Zn})$ contamination, to locate pollution hot-spots, and to recognize possible sources of contamination in surface soils of Hamadan Province (Iran) through principal component analysis (PCA) and false color composites (FCC).

\section{Methods}

\section{Study area}

Hamadan Province occupies an area of $19493 \mathrm{~km}^{2}$ (from 33 degrees, 59 minutes to 35 degrees, 48 minutes north latitude and from 47 degrees, 34 minutes to 49 degrees, 36 minutes east longitude) (Figure 1). The agricultural and livestock development of this province $(49.3 \%$ of its lands are used for agricultural purposes) has turned Hamadan into an economic hub (Figure 2). The dominant geological structures of the area include alluvial terraces from the Quaternary period, orbitoline limestone, shale and marl from the late Cretaceous period, metamorphic sandstone from the Jurassic period, and andesitic lava and reef limestone from late Paleogene and early Neogene periods (geological map 1:1000000; Geological Survey of Iran). The area contains shallow to moderatelydeep soils with small to medium-sized gravels and some amounts of calcareous material (2007).

\section{Sampling}

In order to perform systematic random sampling, the area was first divided to $5 * 5 \mathrm{~km}^{2}$ networks. Afterward, based on the characteristics of the area and various types of land use and activities, networks of $2.5 \times 2.5$ and $10 \times$ $10 \mathrm{~km}^{2}$ were developed in areas with intensive and lowintensity land use, respectively. The points where the networks met were selected as sampling points. Finally, 286 soil samples were collected from the area, i.e. after determining sampling points, a $20 \times 20 \mathrm{~cm}^{2}$ macro-plate was drawn at each point. Then, three $3 \times 3 \mathrm{~cm}^{2}$ microplates were drawn inside it in the shape of a downward V. Five soil samples were taken from the four corners

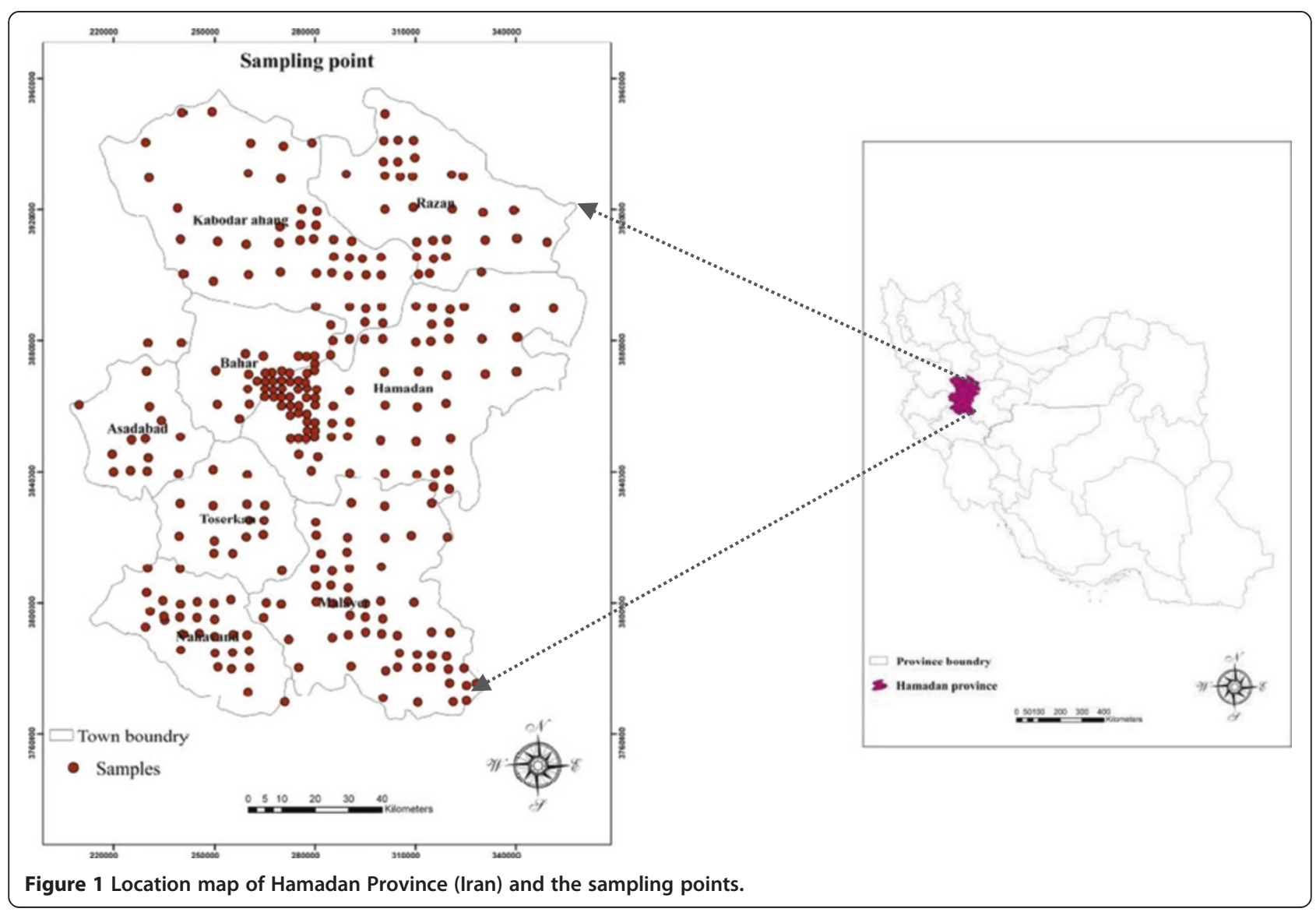




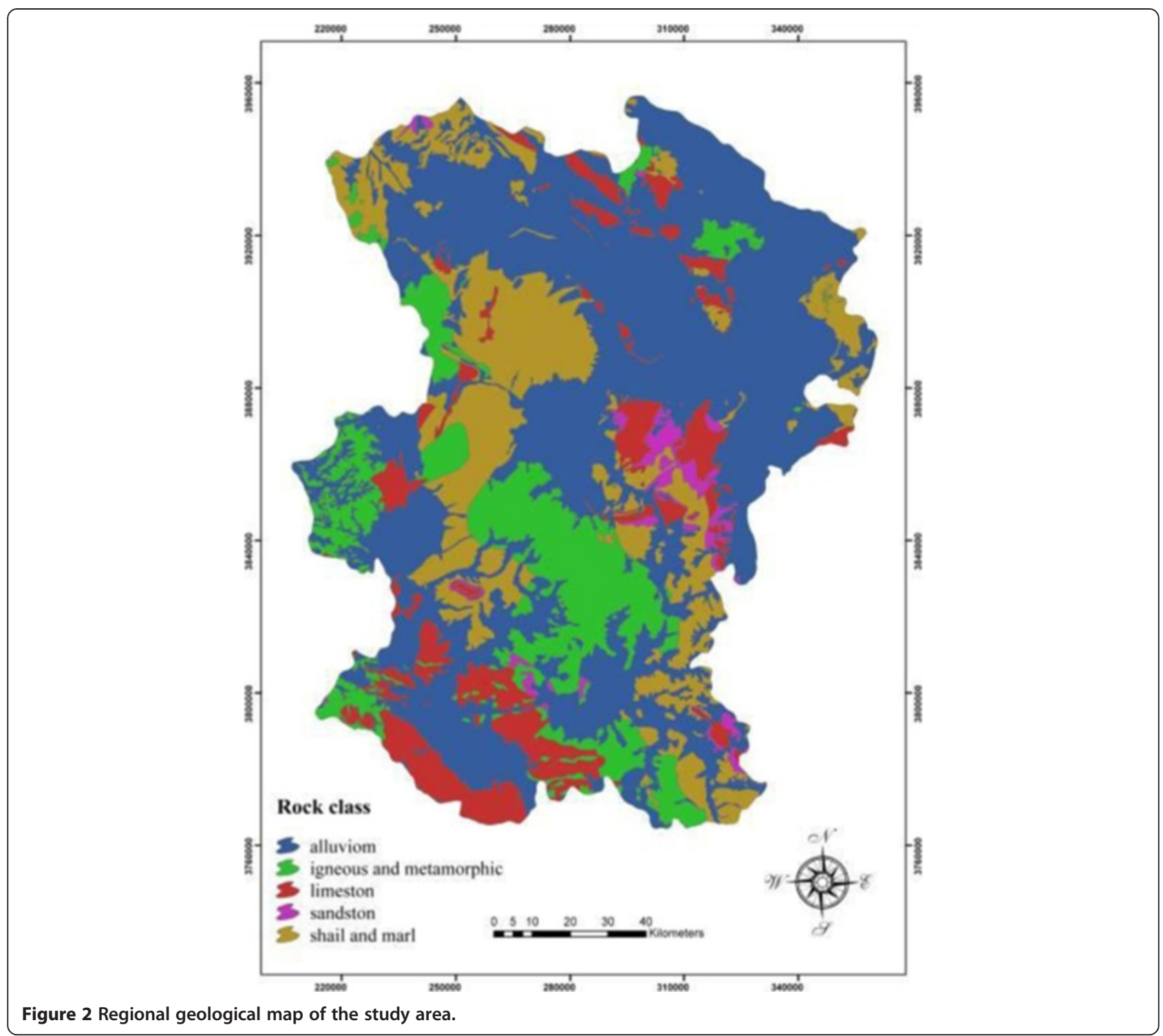

and the center of each micro-plate. The samples were all obtained at depths of $0-20 \mathrm{~cm}$. The collected soils were eventually mixed and a final $2-3 \mathrm{~kg}$ sample was prepared.

Information about land use at the sampling point, type of agriculture (irrigated/rainfed), appearance of the land, kind of product, geographical characteristics, and the nearest village was recorded in a sampling form. Samples were taken from pristine areas as well as mountainous areas, deserts, salt marshes, lands under irrigated or rainfed agriculture, vineyards, gardens, and areas near villages (Figure 3 ).

\section{Chemical analysis of soil}

The prepared samples were sent to the laboratory and their $\mathrm{Pb}, \mathrm{Zn}, \mathrm{As}, \mathrm{Cr}, \mathrm{Co}, \mathrm{Ni}, \mathrm{V}, \mathrm{Fe}$, and $\mathrm{Cu}$ concentrations were measured via inductively coupled plasma-atomic emission spectrometry (ICP-AES). Cd content of the samples was assessed using a graphite furnace and atomic absorption spectroscopy in the chemical laboratory of the Iranian Center for Advanced Mineral Processing Research.

\section{Descriptive statistics}

Kolmogorov-Smirnov test was applied to investigate the normal distribution of data at a confidence level of $95 \%$. Moreover, the data was normalized with logarithmic transformation. In order to evaluate the effects of land use on the concentrations of heavy metals in soil, the map was first divided into three main categories of agricultural, urban-industrial, and non-agricultural use. Pearson's correlation coefficients were then calculate to identify the correlations between heavy metal concentrations and different land uses. A box plot and PCA were used to determine the outliers and classify the relations between the measured variables, respectively. 


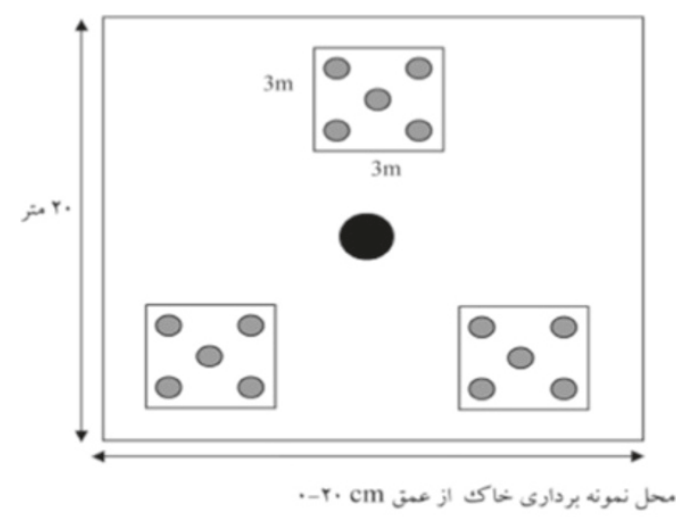

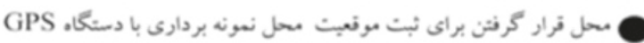

- Soil sampling method in depth of $20 \mathrm{~cm}$

- locations for sampling points record with GPS device.

Figure 3 Sampling method.

\section{Land use mapping}

Considering the importance of land use map in analyzing heavy metal pollution, the map was prepared using Indian Remote Sensing (IRS-P6) Advanced Wide Field Sensor (AWiFS) images.

\section{Data mapping}

The current research employed kriging for data mapping.

\section{False color composition (FCC)}

Geographical information studies may utilize FCC to determine hot-spots of heavy metal pollution. This method can simultaneously compress data and interpret layers of information. Creating color composite images involved spatial correlation analysis of the heavy metals. After standardizing the zoning map of all elements' concentrations $(0-255)$, the three elements in each group were colored as red, green, and blue. The FCC map was then developed accordingly.

\section{Principal component analysis (PCA)}

PCA is a statistical method to classify the relations between the measured variables, i.e. it linearly compresses a set of main data to an essentially smaller set of new, uncorrelated variables which represent nearly all information in the main data set. Meanwhile, understanding and working with a small set of uncorrelated variables is much easier than working with a large set of correlated variables (Eastman 2006). In the present study, PCA was carried out in SPSS for Windows 15.0 (SPSS Inc., Chicago, IL, USA). In addition, spatial correlation analysis was applied for each variable to select the most appropriate method of interpolation. Finally, the zoning map of the factors obtained from PCA was produced in ArcGIS 9.3 (Esri, CA, USA).

\section{Inverse overlaying of elements}

Since the images from the previous stage could not provide information about more than three elements in recognition of pollution hot-spots, the anomalies of elements (distribution of a combination of elements in each area) were determined using the zoning map of elements obtained from FCC, map overlay, and identification of heavy metal hot-spots. Overlaying of inverse layers facilitates analysis by creating an overall view on multiple elements (Suyash Kumar et al. 2007). It is, in fact, a different representation of elements for clearer observation of pollution hot-spots. In order to apply this method, the maps from FCC were first stretched between zero and 255. Afterward, pairs of layers (one as the top and one as the bottom map) were selected according to the correlations between their elements. In top and bottom layers, red to blue and blue to red (reverse) represented maximum to minimum amounts, respectively. Top layers were then demonstrated at a contrast of 100 and transparency of 60 . Finally, similar to FCC, the anomaly of elements was interpreted based on the composition of the obtained colors.

\section{Results}

\section{Filtration and normalization of primary data}

Table 1 summarizes the density of heavy metals (mean As: 15.7993, Cd: 0.1535, Fe: 3.9472, Co: 18.9598, Cr: 96.8182, $\mathrm{Cu}:$ 36.4545, Ni: 69.0350, Pb: 31.8916: Sb: 2.9084, V: 109.4161, Zn: 80.0035). The box plot in Figure 4 was used to correct the outlier data about the concentration of heavy metals. The numbers of outlier and corrected data are given in Table 2. The results of Kolmogorov-Smirnov test showed the data for $\mathrm{As}, \mathrm{Sb}, \mathrm{Cr}, \mathrm{Co}$, and $\mathrm{Pb}$ not to be normal (Table 3). However, normal distribution of variables is essential in geostatistical studies. Moreover, too much stretching and crumpling can damage the structure of variogram and the results of kriging. Therefore, after ensuring the absence of negative data, logarithmic transformation was applied to normalize the concentrations of the mentioned elements (Figure 5). Pearson's correlation analysis was then performed again on the normalized data (Table 4).

Analysis of variance on the mean concentrations of heavy metals in soil did not prove any significant difference between the three different kinds of land use (agricultural, urban-industrial, and non-agricultural uses).

\section{PCA}

The appropriateness of data for PCA is assessed based on Kaiser-Mayer-Olkin (KMO) index, i.e. the test is recommended only if $\mathrm{KMO}>0.70$. Since KMO index was calculated as 0.84 in the current research, PCA was applied on 
Table 1 Trace element data for the soil from Hamadan Province, Iran

\begin{tabular}{llllllll}
\hline Metal & $\mathbf{N}$ & Missing & Minimum & Maximum & Mean & Std. deviation & Europe mean \\
\hline As & 286 & 9 & 4.70 & 85.00 & 15.7993 & 8.94631 & 11.6 \\
$\mathrm{Cd}$ & 286 & 10 & .10 & 0.88 & 0.1535 & 0.08408 & 0.284 \\
$\mathrm{Fe}$ & 286 & 9 & 1.80 & 6.00 & 3.9472 & 0.67775 & 2.17 \\
$\mathrm{Co}$ & 286 & 9 & 8.10 & 34.00 & 18.9598 & 3.89043 & 8.91 \\
$\mathrm{Cr}$ & 286 & 9 & 30.00 & 180.00 & 96.8182 & 26.37480 & 94.8 \\
$\mathrm{Cu}$ & 286 & 9 & 4.00 & 75.00 & 36.4545 & 10.09202 & 17.3 \\
$\mathrm{Ni}$ & 286 & 9 & 26.00 & 140.00 & 69.0350 & 20.43214 & 37.3 \\
$\mathrm{~Pb}$ & 286 & 9 & 13.00 & 1800.00 & 31.8916 & 105.13443 & 32.6 \\
$\mathrm{Sb}$ & 286 & 9 & 0.50 & 28.00 & 2.9084 & 2.69343 & 1.04 \\
$\mathrm{~V}$ & 286 & 9 & 50.00 & 190.00 & 109.4161 & 22.38291 & 68.1 \\
$\mathrm{Zn}$ & 286 & 9 & 35.00 & 200.00 & 80.0035 & 18.74679 & 60.9 \\
Valid N (list wise) & 286 & & & & & & \\
\hline
\end{tabular}

the primary data and 11 factors were found necessary for explaining $100 \%$ of variance. However, as a mere four out of the 11 factors could explain $71.36 \%$ of variance, the low importance of the other seven factors was deduced.

Factor loading was used to determine the relationships between the variables and each factor (Table 5). The first factor explained $39.25 \%$ of variance and its factor load was roughly the same for $\mathrm{Fe}, \mathrm{Zn}, \mathrm{Co}, \mathrm{Cr}, \mathrm{Ni}$, and V. High correlation between these elements can indicate their common origin. The second factor explained $13.12 \%$ of the total variance of element distribution and suggested similarity between $\mathrm{Cd}$ and $\mathrm{Cu}$ (factor load: 0.85 for $\mathrm{Cu}$ and 0.65 for $\mathrm{Cd}$ ). The third factor could only explain 9.55\% of variance. According to the table of eigenvalues, $\mathrm{Pb}$ had a factor load of about 0.75 and was the only element in this factor. The fourth factor explained no more than $9.44 \%$ of variance and included As and $\mathrm{Sb}$ with factor loads of 0.49 and 0.89 , respectively. The remaining factors did not have a significant role in increasing the total variance.

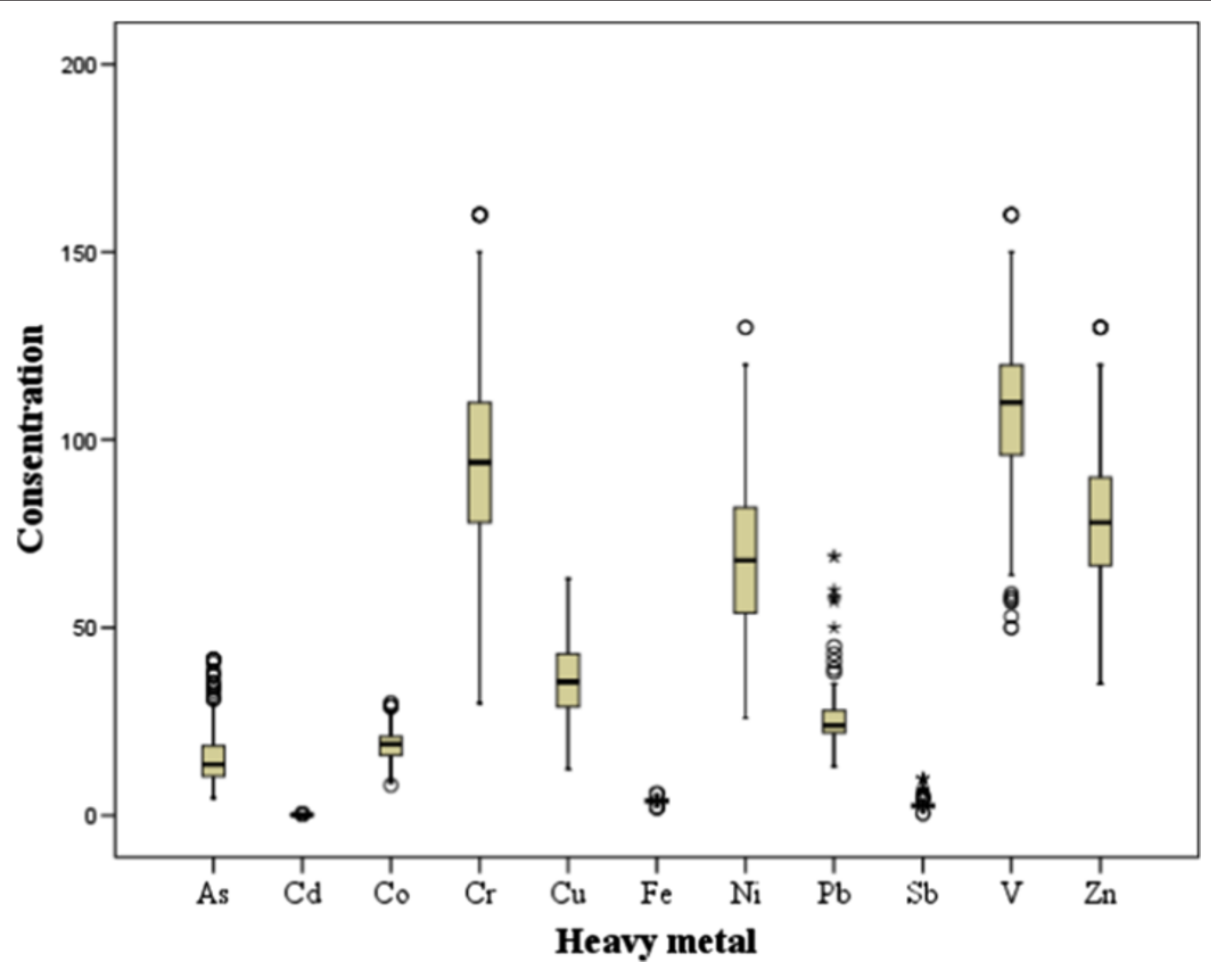

Figure 4 Box plot for outlier determination. 
Table 2 The number of modified and element outlier data for studied heavy metals

\begin{tabular}{|c|c|c|c|c|c|c|c|c|c|c|c|c|}
\hline Element & $\mathrm{Cr}$ & $\mathrm{Ni}$ & v & $\mathrm{Zn}$ & Cd & As & Co & $\mathrm{Cu}$ & Sb & $\mathbf{F}$ & $\mathrm{Fe}$ & $\mathrm{Pb}$ \\
\hline The number of outliers & 5 & 3 & 10 & 5 & 6 & 12 & 6 & 3 & 16 & 9 & 5 & 11 \\
\hline The number of modified data & 2 & 1 & 2 & 3 & 3 & 4 & 2 & 3 & 5 & 1 & 2 & 6 \\
\hline
\end{tabular}

\section{Spatial distribution of components in PCA}

In order to prepare the zoning maps of factors obtained from the PCA, spatial correlation analysis was conducted for each factor in SPSS (SPSS Inc., Chicago, IL, USA) and the most suitable method of interpolation was selected. Table 6 shows fitted models and the most appropriate methods of interpolation. Geostatistical analyses (Table 7) revealed the exponential model to be the best fitted model for the factors (Figure 6).

\section{Geostatistical analysis}

Kriging and radial basis function (RBF) were employed to investigate the spatial variations of heavy metals. All such analyses were performed in ArcGIS 9.3 (Esri, CA, USA). The precision of the methods was compared using the jack-knife technique and root mean square error (RMSE), mean bias error (MBE), and mean absolute error (MAE) which are all valid indices (Table 7). Based on the results, the most appropriate methods were disjunctive kriging for $\mathrm{Fe}, \mathrm{Zn}, \mathrm{As}$, and $\mathrm{Pb}$, ordinary kriging for $\mathrm{Cr}, \mathrm{Ni}$, $\mathrm{Sb}$, and $\mathrm{Co}$, and $\mathrm{RBF}$ for $\mathrm{Cd}$ and $\mathrm{Cu}$ (Figure 7).

\section{FCC}

According to Pearson's correlation analysis (Table 4), the elements were divided into four groups: Fe, V, and Co; $\mathrm{Cu}, \mathrm{Ni}$, and $\mathrm{Cr} ; \mathrm{Pb}$ and $\mathrm{Zn}$; and $\mathrm{Sb}$ and $\mathrm{Cd}$. Singlecomponent images were standardized $(0-255)$ to prepare the FCC map. Two-three elements were then combined based on the above-mentioned classifications and using the FCC method (Figure 8a and b). As the prepared images did not yield information about more than three elements in recognizing the hot-spots, after standardization of single-component images, the elements were categorized into two groups based on their correlation level.
Consequently, Fe, V, Co, $\mathrm{Cu}, \mathrm{Ni}$, and $\mathrm{Cr}$ were allocated to the first category and $\mathrm{Pb}, \mathrm{Zn}, \mathrm{As}, \mathrm{Sb}$, and $\mathrm{Cd}$ were placed in the second. The two groups were then combined using weighted linear combination (Figure 8c). This process simplified the analysis of hot-spot positions. In other words, to identify the anomalies of the elements (combined distribution of elements in each area), weighted linear combination and overlaying were applied on singlecomponent images and the heavy metal hot-spots were recognized. Red and blue areas in Figure 8c have high and low anomalies, respectively.

\section{Discussion}

\section{Correlation analysis}

The results of spatial correlation analysis (Table 4) showed that the mean estimation error and RMSE for all variables were close to the ideal values (zero and one, respectively). This suggests high precision of our estimations. There was also a great spatial correlation between the concentrations of elements (especially As, Fe, Co, $\mathrm{Ni}$, and $\mathrm{Cr}$ ) in the samples. In other words, the concentrations of elements in closer samples were more similar to each other probably due to the effects of natural factors such as parent material, topography, and soil type. However, human factors (e.g. fertilizing) might have been responsible for weak spatial structure of $\mathrm{Zn}, \mathrm{V}$, and $\mathrm{Pb}$.

MAE and MBE indices were calculated to assess the precision and deviation of interpolation models, respectively (Table 7). As these indices measure the difference between the measured and the estimated values, values closer to zero indicate higher spatial precision of the model and lower deviation, respectively (Hassani-pak 1998; Mohammadi 2006).

Table 3 One-sample Kolmogorov-Smirnov test results about the concentration (in $\mathrm{mg} / \mathrm{kg}$ ) of the studied heavy metals in Hamadan Province, Iran

\begin{tabular}{lllllllllllll}
\hline & & As & $\mathbf{C d}$ & $\mathbf{F e}$ & $\mathbf{C o}$ & $\mathbf{C r}$ & $\mathbf{C u}$ & $\mathbf{N i}$ & $\mathbf{P b}$ & $\mathbf{S b}$ & $\mathbf{V}$ & $\mathbf{Z n}$ \\
$\mathbf{N}$ & & $\mathbf{2 8 6}$ & $\mathbf{2 8 6}$ & $\mathbf{2 8 6}$ & $\mathbf{2 8 6}$ & $\mathbf{2 8 6}$ & $\mathbf{2 8 6}$ & $\mathbf{2 8 6}$ & $\mathbf{2 8 6}$ & $\mathbf{2 8 6}$ & $\mathbf{2 8 6}$ & $\mathbf{2 8 6}$ \\
\hline Normal parameters (a,b) & Mean & 15.49 & .1457 & 3.9479 & 18.9458 & 96.6783 & 36.1612 & 69.0000 & 25.8392 & 2.702 & 109.241 & 79.5839 \\
& Std. Deviation & 7.34 & .0720 & .67360 & 3.84308 & 25.9820 & 9.75556 & 20.3185 & 7.22292 & 1.30851 & 21.8781 & 16.9531 \\
Most extreme differences & Absolute & .15 & .242 & .070 & .098 & .096 & .037 & .078 & .176 & .180 & .116 & .052 \\
& Positive & .15 & .242 & .049 & .098 & .096 & .037 & .078 & .176 & .180 & .116 & .052 \\
& Negative & -.10 & -.220 & -.070 & -.064 & -.050 & -.029 & -.038 & -.116 & -.106 & -.087 & -.039 \\
Kolmogorov- Smirnov Z & & 2.561 & 4.088 & 1.176 & 1.661 & 1.623 & .624 & 1.324 & 2.978 & 3.052 & 1.954 & .875 \\
Asymp. Sig. (2-tailed) & & .000 & .054 & .126 & .008 & .010 & .831 & .060 & .000 & .000 & .064 & .428 \\
\hline
\end{tabular}




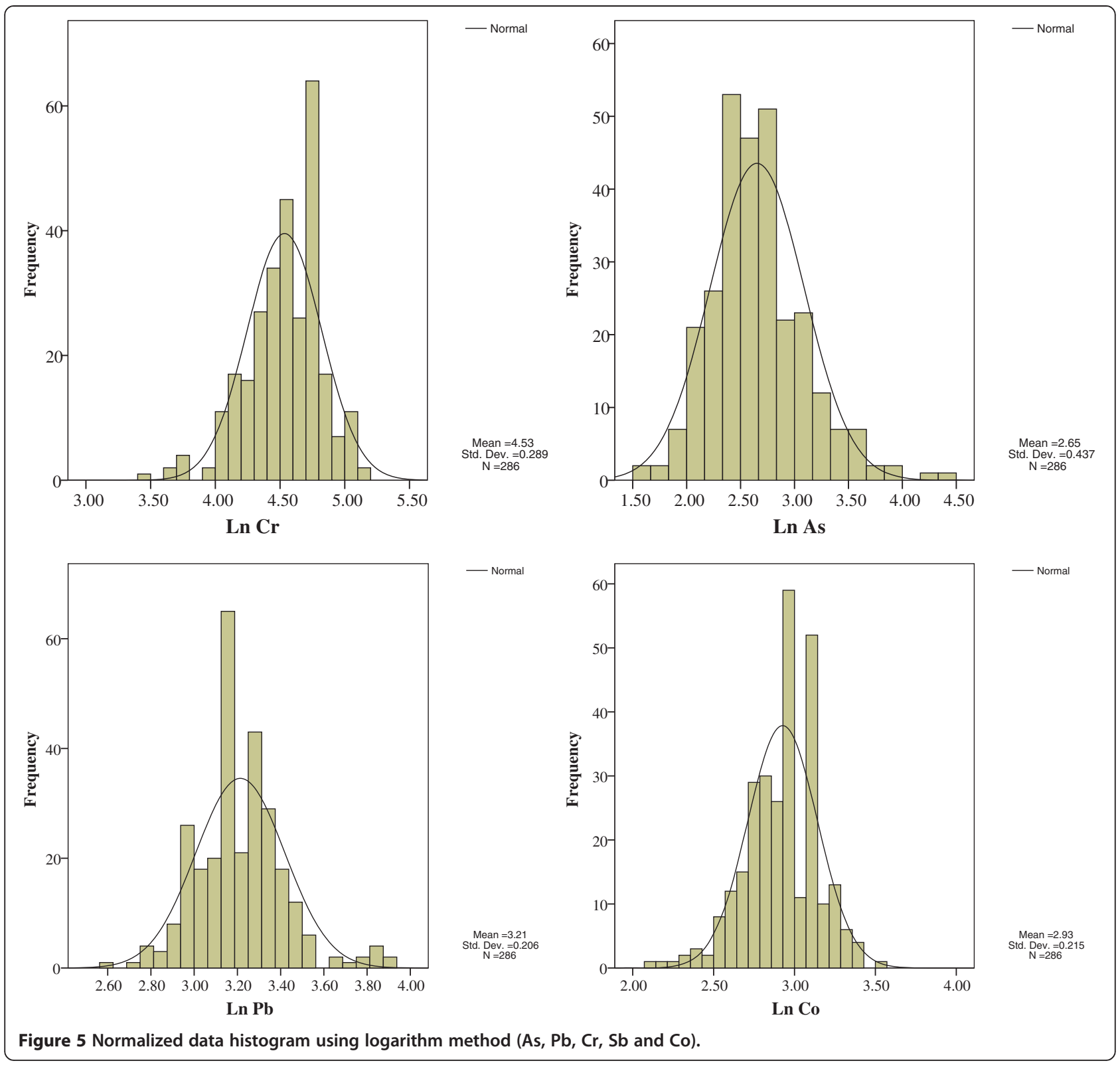

\section{Zoning maps}

According to the distribution map of As (Figure 7), the element had the highest concentrations $(20-50 \mathrm{mg} / \mathrm{kg}$ ) in the northwest, two spots in the southwest and some spots in the center of the province. The geological structure of these areas comprised metamorphic rocks, shale, marl, and limestone.

The distribution maps showed the highest concentrations of Fe, Ni, Cr, and Co to be 4.0-5.9, 90-130, 140160 , and $20-30 \mathrm{mg} / \mathrm{kg}$, respectively. These hot-spots were detected in the form of some red spots in the west, southwest, and northwest of the province. Furthermore, the bedrock was shale, igneous and alluvial rocks, and sandstone for $\mathrm{Fe}$ and $\mathrm{Ni}$, limestone and igneous rocks for $\mathrm{Cr}$, and shale-marl, sandstone, limestone, and metamorphic rocks for Co.

The highest concentration of $\mathrm{Cd}$ in the studied soils varied between 0.30 and $0.35 \mathrm{mg} / \mathrm{kg}$ (Figure 7) and was demonstrated as some spots throughout the province. It was found on geological structure of shale-marl, limestone, and alluvial rocks.

The distribution map of $\mathrm{Zn}$ suggested the maximum level of the element $(100-130 \mathrm{mg} / \mathrm{kg})$ to exist in the west, southeast, northeast, and partly in the center of the province on limestone, metamorphic rocks, and shale bedrocks.

The greatest concentration of $\mathrm{Sb}$ ranged from 5.0 to $9.8 \mathrm{mg} / \mathrm{kg}$ (Figure 7) and was seen in the form of two spots on igneous stones and shale bedrocks. 
Table 4 Pearson's correlation coefficients between the heavy metals

\begin{tabular}{|c|c|c|c|c|c|c|c|c|c|c|c|}
\hline & LnCo & LnSb & LnPb & $\mathrm{LnCr}$ & LnAs & $\mathrm{Zn}$ & v & $\mathrm{Ni}$ & $\mathrm{Cu}$ & $\mathrm{Cd}$ & $\mathrm{Fe}$ \\
\hline LnCo & 1 & & & & & & & & & & \\
\hline LnSb & $.616^{(* *)}$ & 1 & & & & & & & & & \\
\hline $\mathrm{LnPb}$ & .108 & .093 & 1 & & & & & & & & \\
\hline $\mathrm{LnCr}$ & $.159(* *)$ & .085 & $.396(* *)$ & 1 & & & & & & & \\
\hline LnAs & .018 & -.069 & .098 & .043 & 1 & & & & & & \\
\hline $\mathrm{Zn}$ & $.704(* *)$ & $.4911^{(* *)}$ & .093 & $.168^{(* *)}$ & .031 & 1 & & & & & \\
\hline V & $.860\left(^{* *}\right)$ & $.553^{(* *)}$ & $.160^{(* *)}$ & $.224(* *)$ & .023 & $.709\left(^{* *}\right)$ & 1 & & & & \\
\hline $\mathrm{Ni}$ & .020 & -.014 & $.146\left(^{*}\right)$ & $.472\left({ }^{* *}\right)$ & .058 & -.003 & .072 & 1 & & & \\
\hline $\mathrm{Cu}$ & .082 & -.042 & $.171^{(* *)}$ & $.294\left({ }^{* *}\right)$ & $.196(* *)$ & .100 & .109 & $.521\left(^{* *}\right)$ & 1 & & \\
\hline $\mathrm{Cd}$ & .005 & .008 & .072 & $.196\left(^{* *}\right)$ & -.098 & .055 & .064 & $.263^{(* *)}$ & $.218\left(^{* *}\right)$ & 1 & \\
\hline $\mathrm{Fe}$ & $.899\left(^{* *}\right)$ & $.608^{(* *)}$ & $.116\left(^{*}\right)$ & $.129\left(^{*}\right)$ & .006 & $.729\left(^{* *}\right)$ & $.8511^{(* *)}$ & .007 & .062 & .014 & 1 \\
\hline
\end{tabular}

*Correlation is significant at the 0.05 level (two-tailed).

**Correlation is significant at the 0.01 level (two-tailed).

Overlaying of the distribution maps of As, Fe, Cd, Zn, $\mathrm{Cr}, \mathrm{Ni}$, and $\mathrm{Sb}$, land use maps, and geological strata of the studied area revealed that the distribution pattern of the elements did not conform to the land use pattern of the area. On the other hand, since the concentration of each element is naturally high in its bedrock (Table 8) (De vos et al. 2005), the most important factor affecting the concentration of the mentioned elements in soil must have been the geological structure (bedrock).

As Figure 7 illustrates, areas with $\mathrm{Pb}$ concentration higher than $30 \mathrm{mg} / \mathrm{kg}$ were located in the southeast, center, and west of the province on igneous, metamorphic sandstone, shale, and limestone. Irrigated agriculture, pasture, and mining land use in these areas results in overuse of fertilizers and chemical herbicides in them. Moreover, sandstone and shale naturally have high concentrations of $\mathrm{Pb}$ (Table 8) (De vos et al. 2005).

Table $\mathbf{5}$ Load factors of the studied variables in Hamadan Province, Iran

\begin{tabular}{ccccc}
\hline Heavy metal & \multicolumn{4}{c}{ Component } \\
\cline { 2 - 4 } & $\mathbf{1}$ & $\mathbf{2}$ & $\mathbf{3}$ & $\mathbf{4}$ \\
\hline $\mathrm{As}$ & & & & 0.897 \\
$\mathrm{Cd}$ & & 0.848 & \\
$\mathrm{Fe}$ & 0.901 & & \\
$\mathrm{Co}$ & 0.943 & & & \\
$\mathrm{Cr}$ & 0.898 & & & \\
$\mathrm{Cu}$ & & 0.647 & & \\
$\mathrm{Ni}$ & 0.833 & & & \\
$\mathrm{~Pb}$ & & & 0.791 \\
$\mathrm{Sb}$ & 0.496 & & & \\
$\mathrm{~V}$ & 0.882 & & & \\
$\mathrm{Zn}$ & 0.705 & & & \\
\hline
\end{tabular}

Maximum $\mathrm{Cu}$ and $\mathrm{V}$ content of soil was 50-63 and $120-160 \mathrm{mg} / \mathrm{kg}$, respectively (Figure 7 ). These values were detected in the west, southwest, and southeast of the province as well as some spots in the center. The bedrocks were shale and limestone for $\mathrm{Cu}$ and shale, igneous rocks, sandstone, and limestone for V. The concentration of these two elements is generally high in shale (Table 8). Meanwhile, overlaying of their distribution maps and the area's land use map showed excessive use of fertilizers and chemical herbicides in the agricultural activities performed in these lands. Hence, although the high concentration of $\mathrm{Cu}$ and $\mathrm{V}$ can be mainly justified by natural factors such as shale, lime, and alluvium bedrock, the accumulation of these elements in agricultural lands with unwarranted use of chemical fertilizers (the mean annual use of urea, potash, and phosphate fertilizers is about 500-700, 200-230, and 300-558 kg per hectare, respectively) can be expected.

Comparisons between our findings and the mean values in Europe and the world (Table 9) led to the conclusion that excluding $\mathrm{Cd}$ (which had a concentration lower than that in Europe and the world) and $\mathrm{Pb}$ (whose level was lower than the mean level in Europe), all elements had higher values in the studied area compared to Europe and the world.

Facchinelli et al. (2001) concluded that while $\mathrm{Cu}, \mathrm{Ni}$, $\mathrm{Cr}$, and Co concentrations are controlled by bedrock, and $\mathrm{Pb}$ and $\mathrm{Zn}$ content of soil is influenced by human factors. Similarly, Leo et al. (2007) found $\mathrm{Cu}, \mathrm{Ni}, \mathrm{Zn}$ and $\mathrm{Cr}$ levels and $\mathrm{Zn}$ and $\mathrm{Cd}$ levels to depend on bedrock and human factors, respectively. Mico et al. (2006) reported that the amounts $\mathrm{Cu}, \mathrm{Fe}, \mathrm{Ni}, \mathrm{Zn}, \mathrm{Cr}$, and $\mathrm{Co}$ are affected by bedrocks, but $\mathrm{Cd}$ content changes based on human factors such as the use of phosphate fertilizers. Lado et al. (2008) assessed heavy metals in the soils of Europe and concluded that $\mathrm{Cu}, \mathrm{Pb}, \mathrm{Cd}$, and $\mathrm{Zn}$ have 
Table 6 Models fitted for factors obtained from principal component analysis and selecting the best interpolation method

\begin{tabular}{|c|c|c|c|c|c|c|c|c|}
\hline Factors & Interpolation method & Model & Nugget & Partial sill & Sill & Mean range & Mean & Root mean square \\
\hline Factor 1 & Ordinary kriging & Exponential & 0 & 1.009 & 1.009 & 21035.1 & 0.027 & 0.853 \\
\hline Factor 2 & Radial basis functions & - & - & - & - & - & 0.015 & 1.003 \\
\hline Factor 3 & Radial basis functions & - & - & - & - & - & 0.001 & 0.874 \\
\hline Factor 4 & Radial basis functions & - & - & - & - & - & 0.002 & 0.785 \\
\hline
\end{tabular}

high correlations with agriculture and limestone, whereas $\mathrm{Cr}$ and $\mathrm{Ni}$ levels are related to bedrocks. Inácio et al. (2008) evaluated the soils of Portugal to prepare a geochemical atlas. They suggested revealed that while the concentrations of As and $\mathrm{Cr}$ are controlled by parent material, the amount of $\mathrm{V}$ depends on mining activities (precipitation of ores). Likewise, Jiachun et al. (2004) indicated As content to be controlled by bedrock but to also be relatively dependent on human resources. They found the concentration of $\mathrm{Cd}$ to be affected by not only natural factors but also human activities.

\section{Factor analysis}

As it can be seen in the zoning map of factor 1, correlation coefficients of variables in each sample ranged from -0.93 to +2.76 . High positive correlations existed between the seven elements in the southeast, southwest, and west where igneous and shale bedrocks were present. In contrast, high negative correlations were seen between the seven elements in the east and northwest on shale bedrocks.

Zoning map of factor 2 shows the correlations between the variables of each sample to vary between -1.24 and +4.40. High positive correlations between $\mathrm{Cu}$ and $\mathrm{Cd}$ were detected as four blue spots in the north and center of the province on alluvium bedrock. High negative correlations were demonstrated as orange spots throughout the province on shale, igneous, metamorphic, and limestone bedrock.

According to the zoning map of factor 3, correlations of variables in each sample took values between -1.31 and +4.20. High positive correlations were observed between $\mathrm{Pb}$ and $\mathrm{F}$ on shale and lime bedrocks in the southeast of the province. On the other hand, high negative correlations between the two elements were clear in the west and south (on alluvium bedrock) where agriculture is the most common land use. Other areas had values between these figures.

For factor 4, correlations between variables ranged from -0.84 to +4.14 . High positive correlations between $\mathrm{Sb}$ and $\mathrm{As}$ were observed on shale, lime, igneous, and metamorphic bedrocks in the southeast, northwest, and partly center of the province. High negative correlations occurred on alluvium bedrock in the east of the province where the land is dominantly used for agricultural purposes. Values in other areas lay between these two figures.

Correlations between these metals can indicate their common source, i.e. bedrock. Factor analysis maps can generally yield useful results about the source of heavy metals. In fact, negative and positive correlations mainly suggest the effects of human activities and geological sources, respectively.

In a study on heavy metal $(\mathrm{Zn}, \mathrm{Cd}, \mathrm{As}, \mathrm{Pb}, \mathrm{Ni}, \mathrm{Cu}$, and $\mathrm{Hg}$ ) pollution and landscape patterns, Pin Lin et al. (2002) categorized the metals using factor analysis and then prepared the zoning maps of four factors. They concluded that the first $(\mathrm{Ni}, \mathrm{Cd}$, and $\mathrm{Cr})$ and second factors $(\mathrm{Pb}, \mathrm{Zn}$, and $\mathrm{Cu})$ were transferred to soil as a direct result of human activities. Similarly, studies in Italy (Facchinelli et al. 2001), northern Spain (Gallego et al. 2002), and other parts of Spain (Rodriguez Martin et al. 2006) classified Cr, $\mathrm{Co}$, and $\mathrm{Ni}$ in the same factor and found them to be controlled by parent material of soil.

Moller (2005) reported that $\mathrm{Cu}$ in urban areas is produced following human activities. Mico et al. (2006) and Franco-Uria et al. (2009) suggested $\mathrm{Cd}, \mathrm{Cu}, \mathrm{Pb}$, and $\mathrm{Zn}$ concentrations to change mainly through human activities. Rodriguez Martin et al. (2006) mentioned transportation and traffic as the main factors contributing to high levels of $\mathrm{Zn}$ and $\mathrm{Pb}$ in the soils of Spain. Mico et al. (2006) claimed that $\mathrm{Pb}$ is transferred to agricultural soils of Spain via atmospheric deposition and use of chemical fertilizers. On the contrary, Fe, Cr, and Co levels are basically controlled by parent material (Franco-Uria et al. 2009).

\section{FCC analysis}

FCC colors the three elements in each group as red, green, and blue. For instance, in a composition of $\mathrm{As}, \mathrm{Zn}$, and $\mathrm{Pb}$, blue, red, and green will represent high concentrations of $\mathrm{As}, \mathrm{Zn}$ and $\mathrm{Pb}$, respectively. High levels of all elements will result in white areas. Black, on the other hand, shows minimum concentrations of all three elements. Therefore, as Figure 8 suggests, these three element had maximum levels in the southeast, northwest, west, and southwest of the province. $\mathrm{Cd}, \mathrm{Fe}$, and Vas well as $\mathrm{Cr}, \mathrm{Ni}$, and $\mathrm{Cu}$ (Figure 8a) had the highest concentrations in the west, southwest, and southeast of the province. In Figure $8 \mathrm{~b}$, the green and red areas correspond high levels of $\mathrm{Sb}$ and $\mathrm{Cd}$, respectively. 
Table 7 Results of spatial correlation analysis and the fitted models

\begin{tabular}{|c|c|c|c|c|c|c|c|c|c|c|c|c|c|c|}
\hline Element & No. sample & Interpolation & Model & Nugget $\left(C_{0}\right)$ & Partial sill (C) & Sill $\left(C_{0}+C\right)$ & Major & Mean & RMS & Root- mean & Trend & MAE & MBE & Anisotropy \\
\hline & & & & & & & & & & & & & & Isotropy \\
\hline As & 286 & Disjunctive kriging & Exponential & 0.4 & 0.8 & 1.2 & 106 & 0.076 & 7.085 & 1.16 & no & 5.13 & 0.076 & 344.5 \\
\hline $\mathrm{Zn}$ & 286 & Disjunctive kriging & Exponential & 0.36 & 0.54 & 0.9 & 29.39 & -0.059 & 14.6 & 1.046 & no & 11.48 & 0.059 & * \\
\hline $\mathrm{Cu}$ & 286 & Radial basis function & - & - & - & - & - & .068 & 9.3 & - & - & 7.42 & 0.045 & - \\
\hline V & 286 & Disjunctive kriging & Exponential & 0.31 & 0.6 & 0.91 & 16.919 & -0.92 & 19.22 & 1.003 & no & 14.85 & .094 & * \\
\hline $\mathrm{Ni}$ & 286 & Ordinary kriging & Spherical & 177.29 & 437.7 & 614.99 & 178 & .034 & 15.98 & 1.068 & no & 12.54 & .34 & * \\
\hline Co & 286 & Ordinary kriging & Exponential & 7.89 & 10.67 & 18.56 & 178.01 & 0.0005 & 3.21 & 1.025 & no & 2.53 & 0.005 & * \\
\hline $\mathrm{Pb}$ & 286 & Disjunctive kriging & Exponential & 0.39 & 0.49 & 0.88 & 13.49 & 0.018 & 6.68 & 1.09 & no & 4.06 & 0.018 & * \\
\hline $\mathrm{Cd}$ & 286 & Radial basis function & - & - & - & - & - & 0.002 & 0.097 & - & - & 0.67 & 0.002 & - \\
\hline $\mathrm{Fe}$ & 286 & Disjunctive kriging & Exponential & 0.52 & 0.7 & 1.22 & 123.97 & 0.0005 & 0.58 & 1.05 & no & 0.46 & 0.00005 & * \\
\hline $\mathrm{Cr}$ & 286 & Ordinary kriging & Exponential & 241 & 669 & 910 & 178 & 0.006 & 20 & 1.11 & no & 16.25 & 0.006 & * \\
\hline $\mathrm{Sb}$ & 286 & Ordinary kriging & Exponential & 0.086 & 0.111 & 0.197 & 178 & 0.042 & 0.35 & 1.14 & - & 0.74 & 0.0048 & 325.5 \\
\hline
\end{tabular}



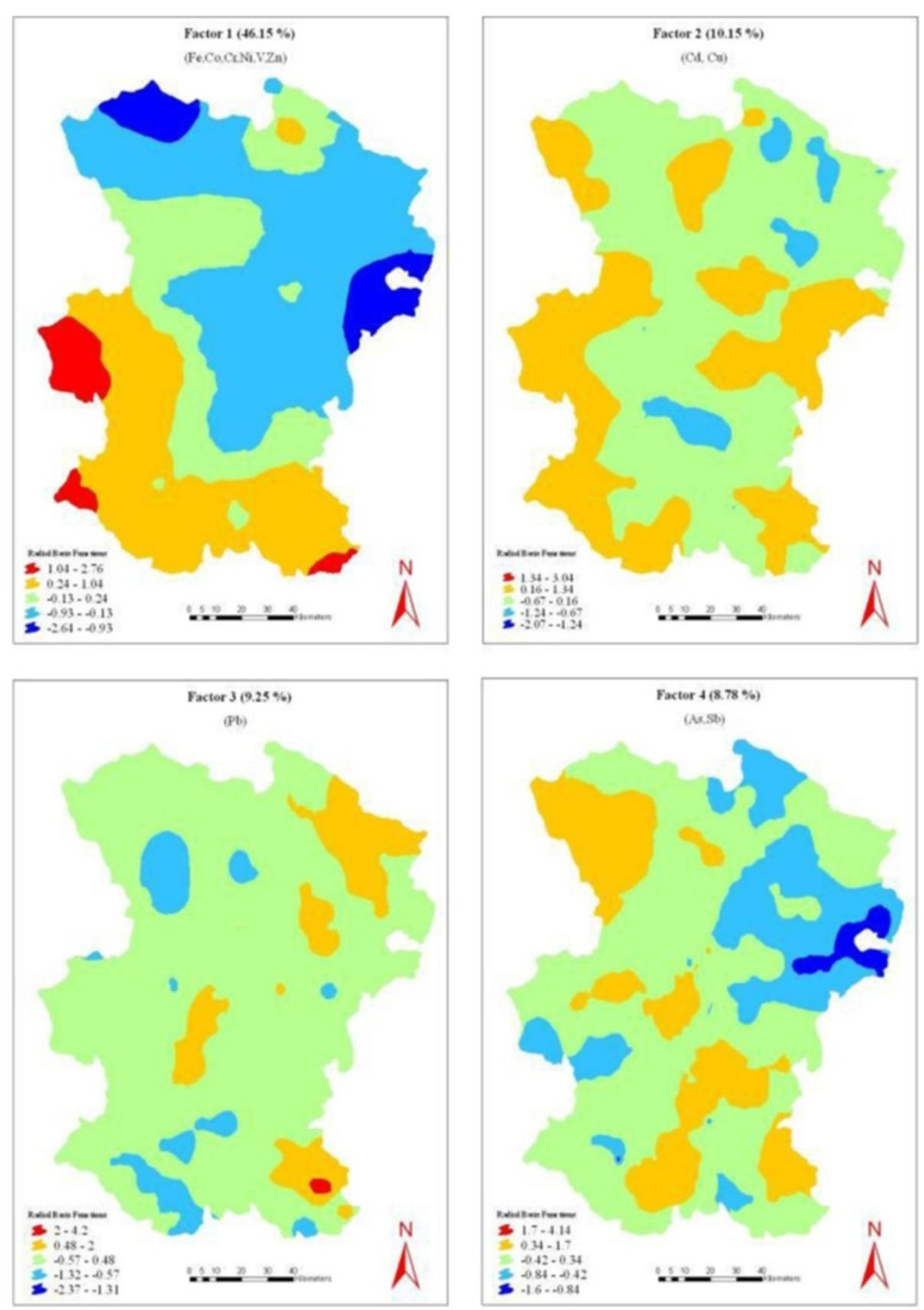

Figure 6 The first factor zoning maps ( $\mathrm{Zn}, \mathrm{V}, \mathrm{Ni}, \mathrm{Cr}, \mathrm{Co}, \mathrm{Sb}$ and Fe); The second factor ( $\mathrm{Cu}$ and $\mathrm{Cd}$ ) zoning maps; The third factor (Pb) zoning map; and the fourth factor (As and $\mathrm{Sb}$ ).

In the maps produced by combining single-component images through weighted linear combination (Figure 8c), red areas (e.g. area number 1) illustrate high amounts of all five elements (As, $\mathrm{Zn}, \mathrm{Pb}, \mathrm{Cd}$, and $\mathrm{Sb}$ ). These areas were located on shale, alluvium, and igneous bedrocks and indicate the hot-spots of the mentioned elements. Areas 2 and 3 (in purple) have a layer with maximum content and a layer with minimum content. In other words, area 2 contained high concentrations of $\mathrm{As}, \mathrm{Pb}$, and $\mathrm{Zn}$ but low levels of $\mathrm{Cd}$ and $\mathrm{Sb}$ which is consistent with its shale, igneous, and alluvium bedrocks. However, the opposite was true in area 3 . Blue areas suggested low values in both layers. In Figure 8c, the elements are at their maximum values in the west, southwest, and southeast. Based on our findings, FCC could clearly depict areas with high and relatively low concentrations of heavy metals. 


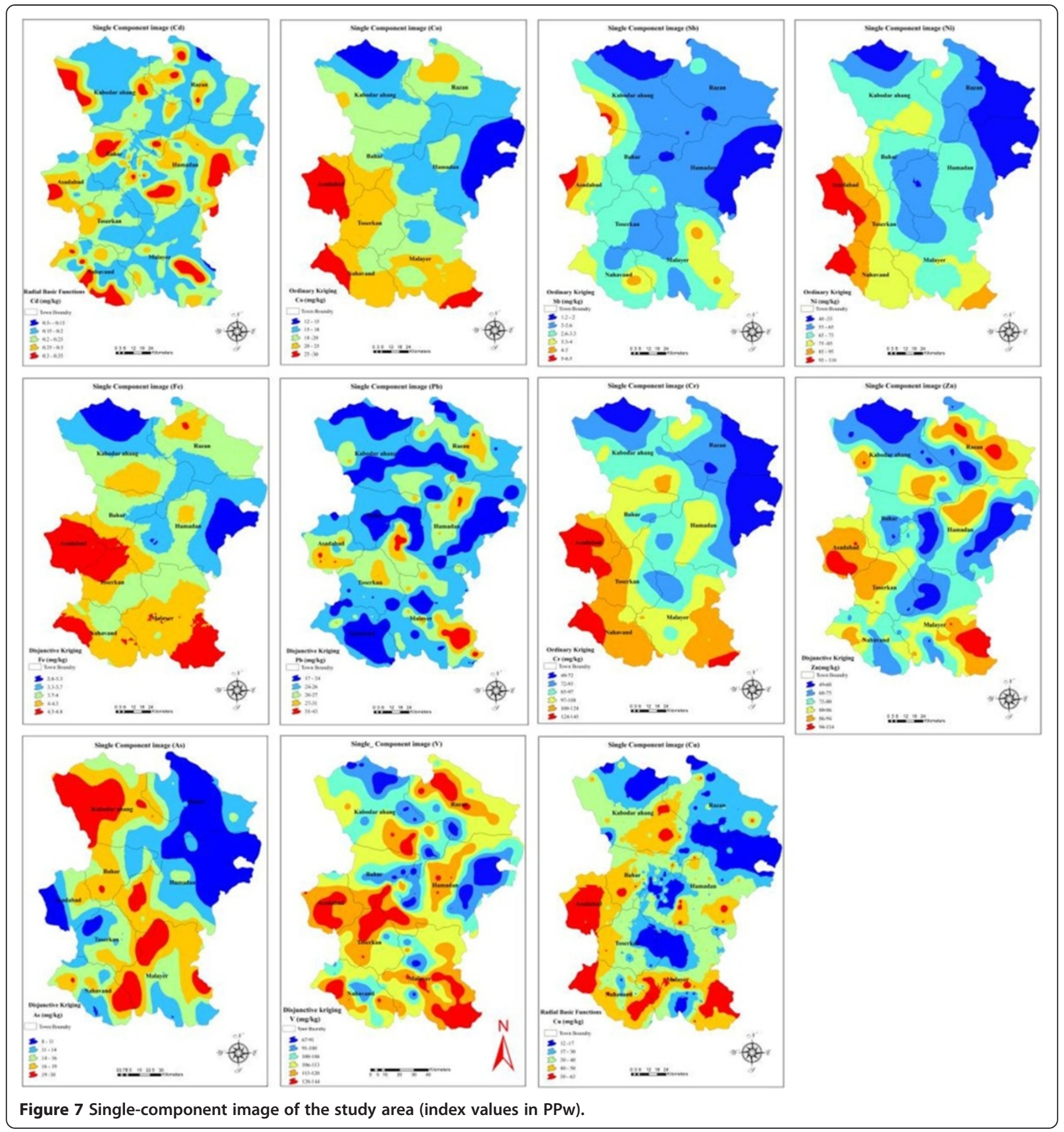

\section{Conclusions}

The current research aimed at locating the hot-spots of pollution with heavy metals. Its most significant findings are summarized below:

Comparison of the mean levels of heavy metals in Hamadan Province and other parts of Iran, suggested higher concentrations of As, $\mathrm{Zn}$ and $\mathrm{V}$ in the studied area than in Isfahan. The mean level of $\mathrm{Zn}$ was higher than that in Mashhad but lower than the value in Sepahanshahr.
The mean concentrations of $\mathrm{Cd}$ and $\mathrm{Pb}$ were lower than the levels in Isfahan and Sepahanshahr, respectively.

Comparisons between the obtained levels and the mean values in Europe and the world (Table 8) revealed that except for $\mathrm{Cd}$ and $\mathrm{Pb}$, the concentrations of all other elements were higher in Hamadan Province than in Europe and the world. Overlaying of land use maps and those obtained from sampling revealed that higher concentrations of some elements in their bedrocks compared 

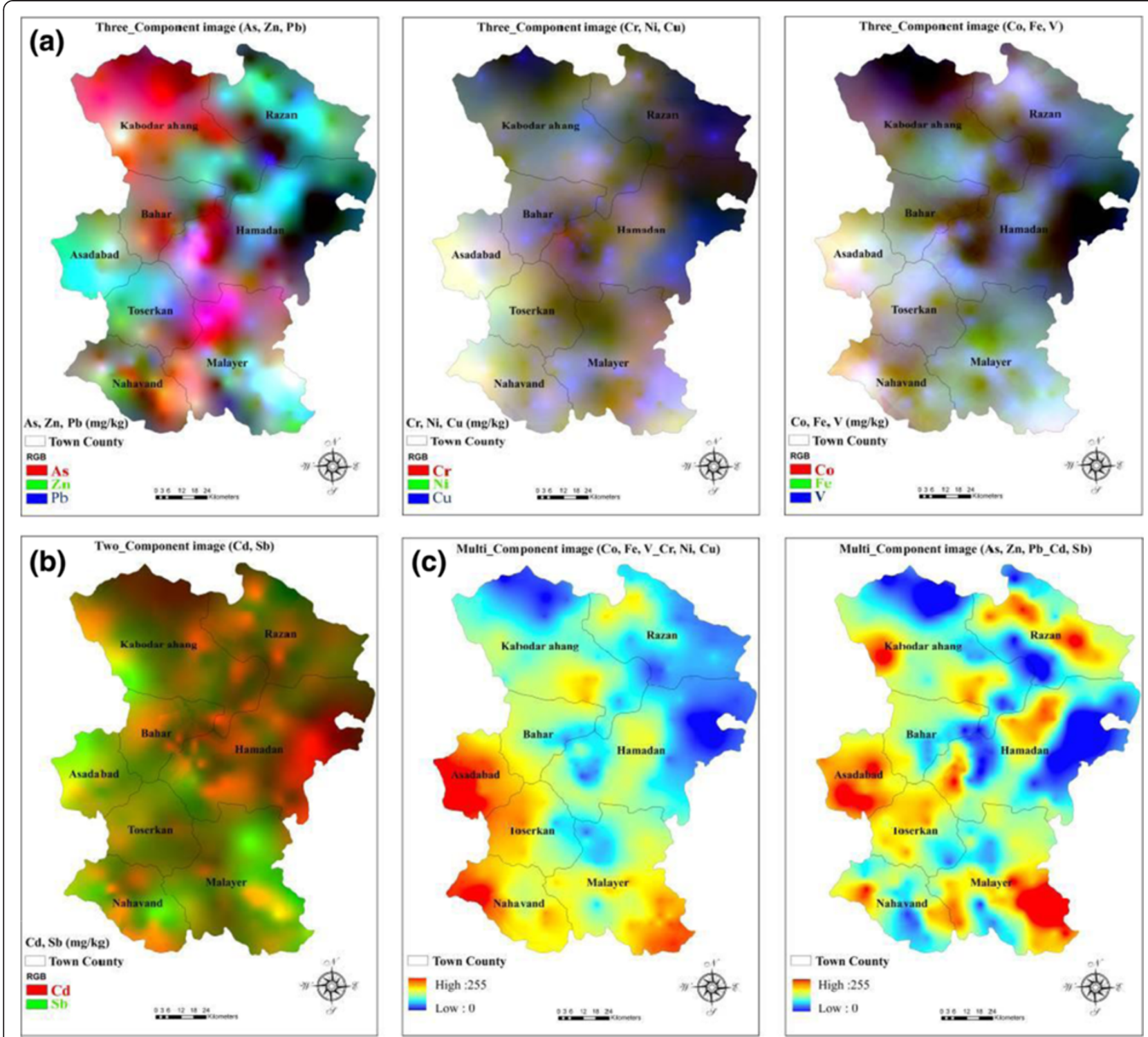

Figure 8 Three-component (a), Two-component (b) and Multi-component (c) color composition of the study area.

to standard levels existed in the agricultural lands where high amounts of chemical fertilizers are used.

Overlaying of zoning maps of the elements and land use and geological layer maps showed that the distribution pattern of the studied elements did not fully conform to the existing land use pattern. On the other hand, as the

Table 8 The mean concentrations of elements in different bedrocks

\begin{tabular}{lllllllllll}
\hline & $\mathbf{C u}$ & $\mathbf{F e}$ & $\mathbf{Z n}$ & $\mathbf{C r}$ & $\mathbf{P b}$ & $\mathbf{N i}$ & $\mathbf{V}$ & $\mathbf{S b}$ & $\mathbf{C d}$ & $\mathbf{C o}$ \\
\hline Ultramafic & 40 & 9.6 & 50 & 1600 & 1 & - & & & 0.09 \\
Sandstone & - & 0.5 & & 35 & 10 & 20 & & $<1$ & \\
Shale & 50 & 4.7 & $50-90$ & 90 & 23 & 90 & $90-260$ & 1.5 & 0.8 \\
Limestone & - & 0.98 & 50 & 11 & - & $<5$ & & 0.15 & \\
\hline
\end{tabular}

level of each element is naturally high in its bedrock, it seems that the main factor affecting the concentrations of heavy metals in the studied soils must have been the geological structure (bedrock). However, excessive use of chemical fertilizers and industrial pollution (in case of $\mathrm{Pb}$ ) should not be ignored.

According to factor analysis, the studied heavy metals lay in four factors. This strong correlation can be caused by a common source of transfer to soil through agricultural activities, atmosphere, or parent material of soil. Moreover, while the measured elements had maximum levels in shale, igneous stone, limestone, and sandstone bedrocks, their concentration was minimum in alluvium.

The zoning maps of pollution probability showed 99.65\% of the area to have Cd values under the threshold. 
Table 9 Comparison of the concentrations of elements in the studied area with the values from the region, Europe, and the world (Facchinelli et al., 2001; Franco-Uria et al., 2009)

\begin{tabular}{lllll}
\hline & Europe mean & Area mean & World median & Area median \\
\hline $\mathrm{As}$ & 11.6 & 15.79 & 5 & 12.5 \\
$\mathrm{Cu}$ & 17.3 & 36.2 & 25 & 35.5 \\
$\mathrm{Fe}$ & 2.17 & 2.94 & 4 & 4 \\
$\mathrm{Cd}$ & 0.284 & 0.15 & 0.3 & 0.11 \\
$\mathrm{Zn}$ & 60.9 & 80.03 & 70 & 76 \\
$\mathrm{Cr}$ & 94.8 & 96.81 & 80 & 94 \\
$\mathrm{Co}$ & 8.91 & 18.95 & 10 & 19 \\
$\mathrm{~Pb}$ & 32.6 & 25.66 & 17 & 24 \\
$\mathrm{Ni}$ & 37.3 & 69.03 & 50 & 68 \\
$\mathrm{~V}$ & 68.1 & 109.41 & 90 & 110 \\
$\mathrm{Sb}$ & 1.04 & 2.9 & 0.5 & 2.5 \\
\hline
\end{tabular}

Meanwhile, $100 \%$ of the area had Co and Sb concentrations higher than the threshold. Levels of $\mathrm{As}, \mathrm{Zn}, \mathrm{Cu}, \mathrm{V}$, $\mathrm{Ni}, \mathrm{Pb}, \mathrm{Fe}$, and $\mathrm{Cr}$ were higher than the determined threshold in $80 \%, 90 \%, 98 \%, 99.7 \%, 70 \%, 98.8 \%, 85 \%$, and $90 \%$ of the studied area. It can thus be concluded that the area had a more appropriate situation regarding $\mathrm{Cd}$ compared to other heavy metals. Greater management and filtering programs are essential to control the transfer of $\mathrm{Co}$, $\mathrm{Sb}, \mathrm{As}, \mathrm{Zn}, \mathrm{V}, \mathrm{Ni}, \mathrm{Pb}, \mathrm{Fe}$, and $\mathrm{Cr}$.

Our findings indicated FCC to be an appropriate and fast method for analyzing heavy metal pollution hotspots. Weighted linear combination could also locate the hotspots by clear depiction of areas with high and relatively low levels of heavy metals.

\section{Competing interests}

The authors declare that they have no competing interests.

\section{Authors' contributions}

All authors read and approved the final manuscript.

\section{Author details}

${ }^{1}$ Department of Natural Resources, Isfahan University of Technology, Isfahan 84156-93111, Iran. 'Environmental Sciences, Department of Natural Resources, Isfahan University of Technology, Isfahan 84156-93111, Iran. ${ }^{3}$ Department of Agriculture, Payam-e-Noor University, Ardestan 83818-98951, Iran.

Received: 14 October 2013 Accepted: 26 December 2013 Published: 15 January 2014

\section{References}

(2007) investigation of sludge disposal positioning in Hamadan province, meteorological reports, hydrology, geology, pedology, tectonic seismic prone and integrating to GIS. University of Shahid Beheshti research assistant Blom HA (1985) Heavy metal contamination of soils. Agri Univ, Norway Bonham-carter GF, Rogers PJ, Ellwood DJ (1987) Catchment basin analysis applied to surficial geochemical data, Cobequid highlands, Nova Scotia. J Geochem Explor 29:259-278

Bowen HJM (1979) The environmental chemistry of elements. Academic press, London, New York
De vos W, Batista MJ, Demetriades A, Duris MJ, Lexa J, Lis J, Sina K, O' c PJ (2005) Metallogenic mineral provinces and world class Ore deposits in Europe. In: Salminen R, Batista MJ, Bidovec M, Demetriades A, De Vivo B, De Vos W, Duris M, Gilucis A, Gregorauskiene V, Halamic J, Heitzmann P, Lima A, Jordan G, Klaver G, Klein P, Lis J, Locutura J, Marsina K, Mazreku A, O'Connor PJ, SÅ O, Ottesen RT, Petersell V, Plant JA, Reeder S, Salpeteur I, Sandström H, Siewers U, Steenfelt A, Tarvainen T (ed) Geochemical Atlas of Europe: part 1 background information, methodology and maps. Geological Survey of Finland

Eastman JR (2006) Idrisi Andes - tutorial, Clark Labs. Clark University, Worcester, MA Facchinelli A, Sacchi E, Mallen L (2001) Multivariate statistical and GIS-based approach to identify heavy metal sources in soils. Environ Pollut 114:313-324

Franco-Uria A, Lopez-Mateo C, Roca E, Fernandez-Marcos ML (2009) Source identification of heavy metals in pastureland by multivariate analysis in NW Spain. J Hazard Mater 165:1008-1015

Gallego JLR, Ordonez A, Loredo I (2002) Investigation of trace. "Element sources from an industrialized area (A viles, northern Spain) using multivariate statistical methods". Environ 27:589-596

Hassani-pak A (1998) "geo statistic", the second edition. University of Tehran press, Iran, pp 286-314

Inácio M, Pereira V, Pinto M (2008) The soil geochemical Atlas of Portugal: overview and applications. J Geochem Explor 98:22-33

Jiachun S, Haizhen W, Jiaming X, Jianjun W, Xingmei L, Haiping Z (2004) Spatial distribution of heavy metal in soils: a case study of changing. China. Environ Goel 52:1-15

Lado LR, Hengel T, Reuter HI (2008) Heavy metals in European soils: a geostatistical analysis of the FOREGS geochemical database. Geoderma 148:189-199

Lame B, Leenaers L (1997) International ash working group. EEA, Brussels. 1999

Lindsay WL (1979) Chemical equilibria in soils. John Wiley \& Sons, New York

Mico C, Recatala L, Peris M, Sanchez J (2006) Assessing heavvy metal sources in agricultural soils of an European Mediterranean area by multivariate analysis. Chemosphere 56:863-872. doi:810.1016/J.Chemosphere. 2006.1003.1016

Mohammadi J (2006) "Pedometry", the second volume, spatial statistic. pelk press, pp 262-279

Moller A (2005) Urban soil pollution in Damascus, Syria: concentrations and patterns of heavy metals in the soils of the Damascus Ghouta. Geoderma 124:63-71

Pin Lin Y, Teng TP, Chang TK (2002) Multivariat analysis of soil heavy metal pollution and landscape pattern in Changhua county in Taiwan. Landscape Urban Plan 62:19-35

Rodriguez Martin JA, Lopez Arias M, Grau Corbi JM (2006) Heavy metal contents in agricultural topsoils in the Ebro basin (Spain): application of multivariate geostatistical methods to study spatial variations. Environ Pollut 144:1001-1012

Romic M, Hengl T, Romic D, Husnjak S (2007) Representing soil pollution by heavy metals using continous limitation scores. Comput Geosci 33:1316-1326

Suyash Kumar KD, Shirke N, Pawar J (2007) GIS-based colour composites and relays to delineate heavy metal contamination zones in the shallow alluvial aquifers, Ankaleshwar industrial estate, south Gujarat, Ipdia. Environ Geol 54:117-129

doi:10.1186/2193-2697-3-3

Cite this article as: Soffianian et al:: Risk assessment of heavy metal soil pollution through principal components analysis and false color composition in Hamadan Province, Iran. Environmental Systems Research 2014 3:3 